\title{
Temporary Food Handlers' Compliance with Effective Food-Hygiene Practices
}

\author{
Mazni Saad'1 , Toh Poh See², \\ Mohamed Azam Mohamed Adil ${ }^{3}$ \\ 1 Faculty of Business, \\ Universiti Selangor, 40000 Shah Alam, Selangor, Malaysia \\ 2 Faculty of Hotel and Tourism Management, \\ ${ }^{3}$ Academy of Contemporary Islamic Studies, \\ Universiti Teknologi MARA, 40450 Shah Alam, Selangor, Malaysia \\ maznisaad@unisel.edu.my
}

\begin{abstract}
Success in food handling depends, in part, on a self-regulation practice factor that accounts for better results in food safety. A self-report study conducted on 318 food handlers reveal that temporary workers were able to comply with the overall hygiene practices outlined in the 1983 Malaysian Food Act and the 2009 Food Hygiene Regulations. This study also shows that proper training of these workers could result in high-level hygiene practices at public food service institutions that would satisfy the community's appetite for safe and healthy food.
\end{abstract}

Keywords: Hygiene practices; temporary workers; food handlers; community health

eISSN 2398-4295 @ 2018. The Authors. Published for AMER ABRA cE-Bs by e-International Publishing House, Ltd., UK. This is an open-access article under the CC BY-NC-ND license (http://creativecommons.org/licenses/bync-nd/4.0/). Peer-review under responsibility of AMER (Association of Malaysian Environment-Behaviour Researchers), ABRA (Association of Behavioural Researchers on Asians) and cE-Bs (Centre for EnvironmentBehaviour Studies), Faculty of Architecture, Planning \& Surveying, Universiti Teknologi MARA, Malaysia.

DOI: http://dx.doi.org/10.21834/ajbes.v3i10.91 


\subsection{Introduction}

Institutional foodservice businesses offer meal services to residents in universities, schools, senior centers, military, prisons, and residential programs. In Malaysia, the government allocates a substantial budget towards developing programs like the national service training program although allocation towards foodservice infrastructure is only a small part of the larger organizational mission. The modus operandi of these government-controlled food services is to finance its food service operation. Insufficient funding very often creates a situation where a little focus is given to enhancing personnel competence or ensuring the availability of much-needed infrastructures such as food warmers or walk-in cooler monitors or commercial freezers that are equipped with a digital temperature reading. This, therefore, puts institutional foodservice as the non-commercial sector of the foodservice industry (Sue Grossbauer, 2001), which has to accommodate reduced funding or subsidies despite having to generate greater quality food, conform to the needs of customers and yet compete in the marketplace. More importantly, the health community is now challenging its ability to have and to maintain its food safety standards at a level required of a public foodservice institution.

Institutional foodservice often operates a seven-day week where a large number of people must be served quickly in a short time. This has been identified as the main cause of many foods handling errors (Jacxsens, 2009), where mistakes like controlling cooking temperature and improper holding time of food which are ready to be served occur (Griffith, 2006; Mazni, Toh, Mohamed Azam, \& Debbie, 2012). The situation becomes more complicated when there is a shortage of manpower. So part of the initiative taken by food services to overcome the problem is to use the services of contract labour. This is done despite the perception that temporary workers often compromise hygiene standards.

Matters related to hygiene practices have to be taken seriously by all parties involved in foodservice because one food-borne illness outbreak can have a devastating consequence on public health (Serraino et al., 2010). Furthermore, the 56 incident rate per 100,000 Malaysian populations (Ministry of Health, 2012) for food and water-borne diseases could be considered as dangerous. Even more worrisome is the presence of other communicable diseases like cholera, hepatitis $A$, typhoid, and dysentery reported in the same year. Figure 1 demonstrates the significant increase in food poisoning cases within twelve years at a phenomenal rate of 25 times more than normal.

Microbiological hazards have been identified as a causing factor to foodborne diseases in the Malaysian food industry. Recent health risk assessments reported that food-borne diseases may have been triggered by several factors like improper food handling training, the use of untreated water for non-drinking purposes, and low sanitation and hygiene status (Ministry of Health, 2012). Food handlers, too, could be a contamination source as they have been implicated in almost 10 to $20 \%$ of such disease outbreaks (Nyi, 2007).

This study, therefore, aims to find out if food services in a developing country like Malaysia, which largely depends on the critical service of temporary workers, are compromising hygiene standards. 


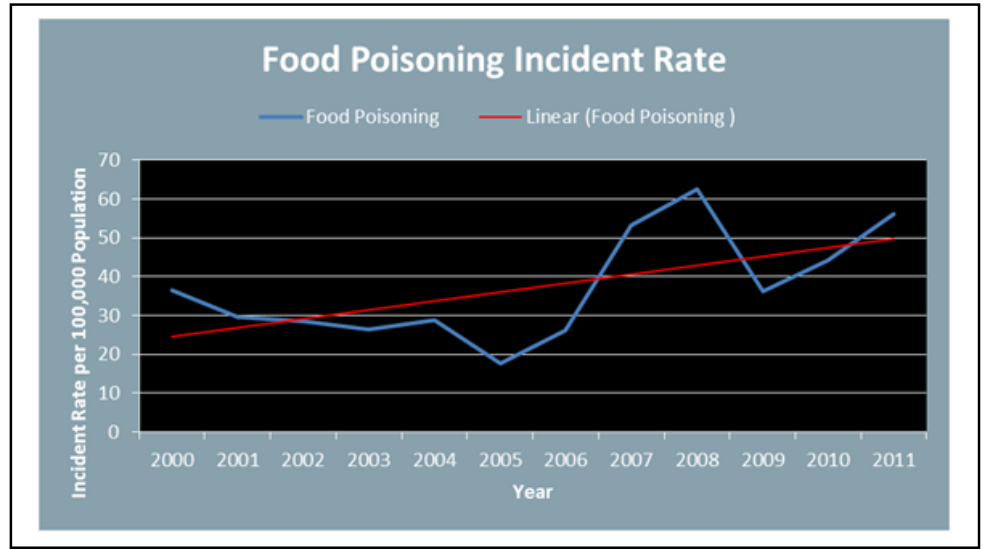

Figure 1: Food poisoning incident rate

\subsection{Literature Review}

\section{Food Handlers}

Food handlers are directly involved in food preparation, come into contact with food or foodcontact surfaces, and handle packaged or unpackaged food or appliances in any food premises (Food Act 1983 [Act 281], 2012). A study on personal hygiene intervention measures (Michaels et al., 2004) found that infected food handlers could transmit infectious intestinal diseases (IID) caused by food-borne pathogens. The study listed 15 organism outbreaks associated with infected food workers and they include Caliciviruses (norovirus), Salmonella spp., Hepatitis A, Shigella spp., Staphylococcus aureus, Streptococcus pyogenes, Salmonella typhi/parathyphi, Vibrio cholera 01, Yersinia enterocolitica, Giardia lamblia, Campylobacter jejuni, Cryptosporidium parvum, Escherichia coli 0157:H7, Cyclospora cayetanensis, and Entamoeba histolytica. Food workers are crucial to food safety as they prepare and cook food, and their correct behavior and appearance contribute to a sanitary environment.

There are permanent and temporary food handlers. The food business in Malaysia is mostly dominated by temporary workers who are contractual and part-time. In most cases they fill up low-skilled, poorly remunerated positions and are tied-free for a particular employer (Lenard \& Straehle, 2012). Very often, the public misjudge their devotion and commitment (Chambel \& Alcover, 2011) as implicit in any short-term position is the workers' inability to contribute fully and commit to standards expected in a job (Bordia, Restubog, Bordia, \& Tang, 2010). Workers are effectively recruited when they fit job specifications and are competent while a contractual one means workers leave their work without much guilt and usually for other life priorities (Casey \& Alach, 2004). This temporary employment situation could raise public concern about the food operations' ability to ensure food safety. 


\section{Hygiene Practices}

Adherence to correct food hygiene practices needs to be understood as the best prevention of most outbreaks (Luyt, 1996). Hygiene refers to "a system of principles for preserving health." Practices are defined as "the actual doing of something", "to do or engage frequently" or "to make the habit of" (Merriam-Webster, 2006). Thus, hygiene practice in this research is conceptualized as a habit engaged in health prevention activities.

Many food operations in Malaysia take preventative measures like applying good manufacturing and hygiene practices. The measures include the use of International Organization for Standardization (ISO) method 9001, Total Quality Management (TQM), and hazard analysis critical control point (HACCP) (Aruoma, 2006). While prevention measures are voluntary, the adoption of hygiene practices is facilitated under the 1983 Food Act [Act 281] and the 2009 Food Hygiene Regulations.

Many studies, for instance, Osimani, Aquilanti, Babini, Tavoletti, \& Clementi (2011) suggest emphasizing preventative food safety measures to combat outbreaks. The emphasis on appropriate hygiene practices for food safety has been for ready-to-eat meals, water sources, contact surfaces, knowledge and attitudes, and effective hygiene intervention strategies (Buccheri et al., 2010; Holvoet, Jacxsens, Sampers, \& Uyttendaele, 2012; Lahou, Jacxsens, Daelman, Van Landeghem, et al., 2012; Michaels et al., 2004; Murphy, DiPietro, Kock, \& Lee, 2011; Tang \& Fong, 2004). Preventative measures for hygiene has also been done through microbial research (Balzaretti \& Marzano, 2012; Lahou, Jacxsens, Daelman, Landeghem, et al., 2012; Rodriguez, Valero, G. D. Posada-Izquierdo, et al., 2011). However, a microbial analysis is costly, time-consuming, and reactive in measures. Conversely, using questionnaire survey to measure hygiene practices is more practical, economical, and able to cover a wider range (Sekaran, 2010).

\subsection{Methodology}

\section{Participants}

The level of food hygiene practices is assessed at the individual level. Operational food handlers working in government institutions make up the target population. They are defined as anyone who is employed exclusively for food preparation and services in the kitchen and dining hall. This cross-sectional research was conducted in October 2012 and covered all 25 kitchen operations of government institutions in four northern states of Peninsular Malaysia: Perlis, Kedah, Penang, and Perak. Food service operations in these training centers are held over three consecutive months three times a year. All trainees rely solely on food and drink provided by them. The training centers have been in operation since 2003, and the kitchen operation is monitored by the Ministry of Health (MOH) through 'Latihan Kendiri' (selfcheck) checklist. The checklist contains hygiene elements for food premises and food handlers.

\section{Research Instrument}

A self-rated questionnaire developed by Bolton et al. (2008) and Martin et al. (1999) was 
adopted to measure food safety practices. The 16-item questions were cross-checked against MOH's 'Latihan Kendiri' (self-check) checklist and the hygiene elements highlighted in the 2009 Food Hygiene Regulations. The instrument was then translated into Bahasa Melayu, Malaysia's national language. Nine questionnaire survey items that focused on food premises and food handlers had negatively worded questions for example "I do not cover my head when my hair is neatly combed" to ensure respondents stay alert and to add fun to the tedious task of answering a questionnaire. Most importantly, it was a strategy employed to ensure that food handlers do not respond instinctively to just one end of the scale.

Prior to data collection, the researcher sought MOH's approval to conduct an investigation of institutions under their jurisdiction. It was also to elicit their comments on the questionnaire survey. Written approval was then issued and attached with the questionnaire.

The IBM SPSS version 21.0 provided descriptive data, factor and reliability analyzes according to the objective of the study. Thus, the mean scores were used for the assessment of hygiene practice level among food handlers.

\subsection{Results and Discussions Profile of the respondents}

Table 1 shows an almost equal number of young male and female food handlers who participated in the survey. They seemed to have quite a broad experience in the food service industry as contract food handlers on normal working hours despite their rather minimal qualification. The majority had been immunized for typhoid and had also attended food handling courses as a minimum requirement for a food service employment. However, about $30 \%$ of the respondents disagreed that a food handling course would help improve their work knowledge. This result in line with the findings obtained from a 2010 risk assessment conducted by the Ministry of Health (Annual Report, 2012). A closer analysis of the demographic pattern and missing data on the highest qualification background $(21 \%)$, there is a possibility that the number of temporary workers is greater than that declared in the statistical data.

\subsection{Conclusion}

This study concludes that government institutional training centers investigated had set up good hygiene practices. The assessment of these practices could provide managers of these premises with considerable information when making projections and decisions about the food they prepare and serve to the public. Generally, the temporary food handlers seem to play quite a significant role in implementing hygiene practices in these food service institutions. Consequently, managers can continue to enjoy higher profits through part-time and contractual workers without having to compromise hygiene quality. As for the future, studies could go for a more accurate analysis of food hygiene practices through a triangulation of methods. Researchers may want to consider involving two or more data simultaneously when assessing the consistency of hygiene practices. Such findings would help generalize current results. Finally, handling food safety in accordance with appropriate 
procedures is good business sense and despite having to address many challenges, food hygiene and sanitation should always be continuously promoted.

Table 1: Profile of Respondents

\begin{tabular}{|c|c|c|c|}
\hline Demographic Variables & Categories & Frequencies & Percentage \\
\hline \multirow[t]{2}{*}{ Gender } & Male & 164 & 52.1 \\
\hline & Female & 151 & 47.9 \\
\hline \multirow[t]{5}{*}{ Age } & Below 18 years old & 19 & 6.1 \\
\hline & 18 to 30 & 150 & 47.9 \\
\hline & 31 to 40 & 62 & 19.8 \\
\hline & 41 to 50 & 49 & 15.7 \\
\hline & Above 50 & 33 & 10.5 \\
\hline \multirow[t]{4}{*}{ Higher Education } & College/University & 11 & 6.8 \\
\hline & Secondary School & 19 & 41.0 \\
\hline & Primary School & 179 & 50.6 \\
\hline & Others & 4 & 1.6 \\
\hline \multirow[t]{3}{*}{ Working Status } & Permanent & 39 & 12.5 \\
\hline & Contract & 230 & 73.5 \\
\hline & Part Time & 44 & 14.1 \\
\hline \multirow[t]{3}{*}{ Working Hours } & Less than 8 hours & 60 & 19.0 \\
\hline & 8 to 10 hours & 206 & 65.4 \\
\hline & More than 10 hours & 49 & 15.6 \\
\hline \multirow[t]{4}{*}{ Working Experience } & Less than one year & 57 & 19.3 \\
\hline & 1 to 5 years & 177 & 60.0 \\
\hline & 6 to 10 years & 54 & 18.3 \\
\hline & More than 10 years & 7 & 2.4 \\
\hline \multirow[t]{2}{*}{ Typhoid Immunization } & Yes & 295 & 98.7 \\
\hline & No & 4 & 1.3 \\
\hline \multirow[t]{2}{*}{ Food handling Course } & Agree & 200 & 70.2 \\
\hline & Disagree & 85 & 29.8 \\
\hline
\end{tabular}

\section{Acknowledgement}

This research was funded by the Ministry of Health, Malaysia through Universiti Teknologi MARA: 100-RMI 37/7/3018 (C060000195). 


\section{References}

Aruoma, O. I. (2006). The impact of food regulation on the food supply chain. Toxicology, 221, 119-127.

Balzaretti, C. M., \& Marzano, M. A. (2012). Prevention of travel-related foodborne diseases: microbiological risk assessment of food handlers and ready-to-eat foods in Northern Italy airport restaurants. Food Control, (JFCO 2812). University of Milan, Italy.

Bordia, P., Restubog, S. L. D., Bordia, S., \& Tang, R. L. (2010). Breach Begets breach: Trickle-Down effects of psychological contract breach on customer service. Journal of Management, 36(6), 1578-1607.

Buccheri, C., C. Mammina, S. Giammanco, M. Giammanco, M. La Guardia, \& Casuccio, A. (2010). Knowledge, attitudes and selfreported practices of food service staff in nursing homes and long-term care facilities. Food Control, $21,1367-1373$.

Casey, C., \& Alach, P. (2004). 'Just a temp?' Women, temporary employment and lifestyle. Work, employment and society, 18(3), 459-480.

Chambel, M. J., \& Alcover, C.-M. (2011). The psychological contract of call-centre workers: employment conditions, satisfaction and civic virtue. Economic and Industrial Democracy, 32(1), 115-134.

Food Act 1983 [Act 281]. (2012). Food Hygiene Regulations 2009. Kuala Lumpur: International Law Book Services.

Griffith, C. J. (2006). Food safety: where from and where to? British Food Journal, 108(1), 6-15.

Hair, J. F., Black, W. C., Babin, B. J., Anderson, R. E., \& Tatham, R. L. (2010). Multivariate Data Analysis (6th. ed.): Prentice Hall International Inc.

Holvoet, K., Jacxsens, L., Sampers, I., \& Uyttendaele, M. (2012). Insight into the Prevalence and Distribution of Microbial McSwane, D., Rue, N., \& Linton, R. (2000). Essentials of Food Safety \& Sanitation (2nd edition ed.). New Jersey: Prentice Hall.

Merriam-Webster. (2006). Merriam-Webster's Online Dictionary Retrieved 15 January 2007, from http://www.mw.com/dictionary/practices

Michaels, B., Keller, C., Blevins, M., Paoli, G., Ruthman, T., Todd, E., \& Griffith, C. J. (2004). Prevention of food worker transmission of foodborne pathogens: risk assessment and evaluation of effective hygiene intervention strategies. Food Service Technology, 4, 31-49.

Ministry of Health. (2012). Annual Report 2010 (pp. 385).

Murphy, K. S., DiPietro, R. B., Kock, G., \& Lee, J. S. (2011). Does the mandatory food safety training and certification for restaurant employees improve inspection outcomes? International Journal of Hospitality Management, 30, 150156.

Nyi, N. N., Maizun, M. Z., Wan Mansor, H., Hamzah, A. M., Noraidatulakma, A., \& Mohd Hilmi, A. B. (2007). A study on effectiveness of health education program on knowledge, attitude and practice (KAP) of food handlers towards foodborne diseases and food safety. International Medical Journal, 14, 253-260.

Osimani, A., Aquilanti, L., Babini, V., Tavoletti, S., \& Clementi, F. (2011). An eight-year report on the implementation of HACCP in a university canteen: impact on the microbiological quality of meals. International Journal of Environmental Health Research, 21(2), 120-132. 
Payne-Palacio, J., \& Theis, M. (2012). Foodservice Management Principles and Practices (12th. Ed. ed.): Prentice Hall.

Rodriguez, M., Valero, A., G. D. Posada-Izquierdo, Carrasco, E., \& Zurera, G. (2011). Evaluation of food handler practices and microbiological status of ready-to-eat foods in long-term care facilities in the Andalusia Region of Spain. Journal of Food Protection, 74(9), 1504-1512.

Sekaran, U. (2010). Research Methods for Business: A skill Building Approach (Fourth ed.). Hoboken, New Jersey: John Wiley \& Sons, Inc.

Serraino, A., Veronese, G., Alonso, S., Matera, R., Lugoboni, B., \& Giacometti, F. (2010). Bactericidal activity of electrolyzed oxidizing water on food processing surfaces. Ital. J. Food Sci., 2(22), 222-228.

Tang, C., \& Fong, U. (2004). A survey of food hygiene knowledge and attitudes among Chinese food handlers

Jacxsens, L., Kussaga, J., Luning, P. A., Spiegel, M. V. d., Devlieghere, F., \& Uytendaele, M. (2009). A microbial assessment scheme to measure microbial performance of food safety management systems. International Journal Food Microbiology, 134, 113-125.

Lahou, E., Jacxsens, L., Daelman, J., Landeghem, F. V., \& Uyttendaele, M. (2012). Microbiological performance of a food safety management system in a food service operation. Journal of Food Protection, 75, 706-716.

Lenard, P. T., \& Straehle, C. (2012). Temporary labour migration, global redistibution, and democratic justice. Politics, Phillosophy \& Economics, 11(2), 206-230.

Levine, D. M., Stephan, D. F., Krehbiel, T. C., \& Berenson, M. L. (2008). Statistics for Managers using Microsoft Excel. New Jersey: Pearson International Edition.

Luyt, S. A. (1996). A study to assess the changes in hygiene of food premises following a specific health education programme. Masters Diploma in Technology (Public Health), Cape Peninsula University of Technology, Cape Town.

Mazni, S., Toh, P. S., Mohamed Azam, M. A., \& Debbie, F. M. (2012, 3-5 Sept 2012). The impact of food safety practices on organizational performance. Paper presented at the International Hotel and Tourism Conference 2012: Journey into Challenging Times for Research \& Innovations, Concorde Hotel, Kuala Lumpur Malaysia

Sue Grossbauer, R. (2001). Managing Foodservice Operations: A System Approach for Healthcare and Institutions (4th. ed.). St. Charles, IL: Dietary Managers Association. 